\title{
Trends in precipitation indices at Akola
}

\section{R.V. MESHRAM, M.M. DESHMUKH AND S.B. WADATKAR}

Article Chronicle : Received: 24.08.2015;

Revised :

30.10.2015;

Accepted :

14.11.2015
Key Words : Precipitation indices, Continuous dry days, Consecutive 5-days rainfall

\begin{abstract}
Climate warming observed over the past several years is consistently associated with changes in a number of components of the hydrological cycle. Precipitation is one of the important component of this cycle. Changes in mean and extreme values of precipitation will impact on rivers, agriculture, environment etc., which may be the serious issue. Therefore predicted trends of precipitation indices can be used to take proper decision for future. In this study the trends in different rainfall indices for the period 1974-2013 were examined for Akola rain gauge station. The meteorological data of rainfall were collected from Agro-Meteorological Observatory, Dr. PDKV Akola. The trends in monthly and annual precipitation indices were calculated statistically and represented graphically. The results showed that there were no significant changes in annual total precipitation within the last few years. In one day maximum rainfall, the decreasing trend was observed during months of monsoon and winter seasons, whereas increasing trends were found during summer months. Maximum number of months showed decreasing trend, especially during monsoon months in respect of consecutive 5days maximum rainfall. The precipitation decrease in August was compensated by a precipitation increase in September. The lengths of wet spells were increased with increase in length of dry spells.

HOW TO CITE THIS ARTICLE : Meshram, R.V., Deshmukh, M.M. and Wadatkar, S.B. (2015).Trends in precipitation indices at Akola. Asian J. Environ. Sci.,10(2): 150-155.
\end{abstract}

Author for correspondence :

\section{M.M. DESHMUKH}

Department of Irrigation and Drainage Engineering, Dr. Panjabrao Deshmukh Krishi Vidyapeeth, AKOLA (M.S.) INDIA

Email: mahendradeshmukh @yahoo.com

See end of the article for Coopted authors' 